\title{
Systems Structure of Education for Sustainable Development in Higher Education Institution
}

\author{
Siti Nur Diyana Mahmud \\ Faculty of Education, Universiti Kebangsaan Malaysia, Bangi, Malaysia \\ Email: diyana@ukm.edu.my
}

How to cite this paper: Mahmud, S. N. D. (2017). Systems Structure of Education for Sustainable Development in Higher Education Institution. Creative Education, 8, 13791400. https://doi.org/10.4236/ce.2017.89097

Received: May 31, 2017

Accepted: July 24, 2017

Published: July 27, 2017

Copyright $\odot 2017$ by author and Scientific Research Publishing Inc. This work is licensed under the Creative Commons Attribution International License (CC BY 4.0).

http://creativecommons.org/licenses/by/4.0/ (c) (i) Open Access

\begin{abstract}
To understand the enactment of Education for Sustainable Development (ESD) in higher education institution (HEI) and why very unequal ESD activity that mostly focused on campus greening rather than on pedagogic reform in HEI requires more than simply an examination of the ESD curriculum and pedagogy. To grasp why and how ESD is implemented in a HEI, the contexts in which it was created and implemented should be considered. Systems structures that include the context of the phenomena can show how the interaction between various factors gives rise to the outcomes that can be observed at the event level which is the enactment of ESD at the HEI. This paper presents a finding of the case study concerning systems structure of ESD conducted at one Malaysia university. This study is explanatory and may give insight to understand ESD enactment in HEI especially in Asian and developing country context. The findings from this study demonstrate that the agents'/ lecturer's individual systems and the organisational/university system are co-evolving with their environment. The changes in the environment, such as the accelerating sustainability crisis and global influence, are perceived by the lecturers as stimulating ESD enactment in the university. The university's response to the sustainability agenda involves temporality and selection. This explained the university's delayed response to the sustainability agenda, until sustainability agenda gained attention globally after the Brundtland Report in 1987.Despite the forces to adapt to environmental changes, within a system there is resistance to change. In this study, it included: the lecturers' perceived lack of sustainability awareness; sustainability acceptance influenced by disciplines; limited financial support from the university; a compartmentalised education system; bureaucratic tensions; and lacking of teaching skills among ESD educators.
\end{abstract}

\section{Keywords}

Systems thinking, Education for Sustainable Development, Higher Education 


\section{Introduction}

The United Nation International Environmental Education Programme (19751995) first introduced the notion of sustainability in Higher Education (HE), and the United Nation encouraged all countries to address Education for Sustainable Development (ESD) by making the period from 2005 to 2014 the Decade for Education for Sustainable Development (DESD). According to UNSECO (2005), Education for Sustainable Development "is a learning process (or approach to teaching) based on the ideals and principles that underlie sustainability and is concerned with all levels and types of learning to provide quality education and foster sustainable human development-learning to know, learning to be, learning to live together, learning to do and learning to transform oneself and society" (p. 30). Tilbury (2007) notes widespread support from university leaders for a number of major international declarations promoting ESD, indicating a commitment to move their institutions towards sustainability. In 1990, in between the Bruntland report and the Earth Summit, the President of Tufts University assembled 22 college Presidents and Chancellors in Talloires, France to discuss their understandings of the planet's deteriorating environment and come up with solutions that they could offer (ULSF, 2011). This group determined that "universities educate most of the people who develop and manage society's institutions. For this reason, universities bear profound responsibilities to increase the awareness, knowledge, technologies, and tools to create an environmentally sustainable future" (Brodie, 2006: p. 2). By March 2012, a total of 437 universities had signed the Talloires declaration and were attempting to apply the principles of sustainability in their university systems (Fadzil et al., 2012). In 2015, the Sustainable Development Goals was launched, the inclusion of HEI as a more significant development actor appears as a positive feature of the new agenda and is able to address previous critiques for its omission (Boni, Lopezfogues, \& Walker, 2016).

The Higher Education Funding Council for England (HEFCE) strategic review in 2008 observed very unequal ESD activity in HEI, and most of it was focused on campus greening rather than on pedagogic reform (SQW Limited, 2006). A similar situation appears to exist in Malaysian HEI. Data from three established, high-ranking public research universities there indicates that universities sustainability programs focus mainly on physical campus greening, green procurement and research on green technology (Omar et al., 2009).

To understand the enactment of Education for Sustainable Development (ESD) in HEI and why very unequal ESD activity in HEI requires more than simply an examination of the ESD curriculum and pedagogy. To grasp why and how ESD is implemented in a university, the contexts in which it was created and implemented should be considered (Lattuca \& Stark, 2009). Systems structures can show how the interaction between various factors gives rise to the outcomes that can be observed at the event level which is the enactment of ESD at the university (Senge, 1990). This paper present a finding of the case study conducted at one Malaysia university. The university was given a pseudonym as 
University A to protect confidentiality of the participants involved in the study. In parallel with the DESD, Malaysia's higher education institutions (HEI) also started initiatives in sustainability implementation in policy, planning and administration, courses and curricula, research and scholarship, university operations, outreaches and services (Derahim, Hashim, \& Ali, 2011; Joseph, 2013; Nair, 2013; Saadatian, Salleh, Tahir, \& Doha, 2011).

To understand the system structure of ESD in University A, the researcher applied a systems-thinking approach. A systems-thinking approach focuses on understanding the interactions between the elements of a system. This study provides insight into the interactions between agents in the systems, elements in the internal and external environments of agents and also the organisation (i.e. University A), and how the agents and organisation adapt to a new, changing environment.

\section{Education for Sustainable Development in Malaysia Higher Education}

The ESD environment in Malaysia's universities is inevitably characterized by globalisation at different levels and in different aspects of the education system (Cheng, 2005; Simon, 2006; Zotzmann, 2007). The educational environment is changing very quickly and becoming very complicated and full of uncertainties and ambiguities. Continuous educational reforms and developments are necessary due to various local and global challenges emerging from this changing education environment. This paper presents the case study that utilized systems thinking approach in order to explore how University A responds to the changing global and local education landscape. This paper explores the literature on how global competitiveness between universities shape the approach and policy of Asian universities in general. Furthermore, this section also focuses on how the process of globalisation affects national and interest group identities, particularly in ESD.

Higher Education Institution (HEI) in Malaysia, like elsewhere, are facing a new kind of competition brought on by globalisation. This is because developing countries such as Malaysia are highly focused on remaining competitive and are fearful of being left out of the development race (Gustavo; Esteva et al., 2013). The Malaysian Government has implemented comprehensive reforms to higher education systems to enhance Malaysia's global competitiveness. Confronted with increasing pressure for global university rankings, governments and Malaysian universities have tried to adopt different strategies in terms of special funding schemes, and different forms of measures in shaping teaching, learning and research activities to enhance their global ranking (Bhandari \& Lefeburee, 2015; Keser, 2015; Mok, 2015). Since the mid-1990s, the pressures of globalisation and the pressing demands of a knowledge economy led to a series of educational reforms, with HEIs having to respond to challenges brought on by globalisation in order to remain competitive (Christopher \& William, 2010; Hadi et al., 2002). One of the challenges of HEIs to remain competitive is to respond to issues that 
apply across borders, for example, climate change, global warming and sustainability issues (UNESCO, 2006). This is because sustainability issues tend to transcend national boundaries and to coalesce around problems shared by neighbouring countries. In the green "common future", as advocated in the Brundtland Report (1987), "sustainable development" has become the motto of the day: that is, to sustain development itself, rather than to sustain nature and culture (Blewitt, 2015; Esteva \& Prakash, 1998). In addition, Jickling and Wals (2012) critique sustainable development as being a conceptually flawed and internally inconsistent concept. Furthermore, Jickling and Wals questioned the "colonialising instrumentality that characterized ESD certainly in its early years when it was superimposed on countries and communities as the new 'flavour of the day"' (Jickling \& Wals, 2012: p. 53).

Malaysian HEIs have been quick to jump on the "bandwagon" of global HEI sustainability initiatives (Abdulrazak \& Ahmad, 2014). This is because in developing countries such as Malaysia, there is an obsession to remain competitive, and a fear of being left out of the economic development race (Gustavo; Esteva et al., 2013). Malaysia Vision 2020, introduced in 1991, calls for the country to achieve a developed-country status by the year 2020. In order to achieve Vision 2020 , the country requires an annual growth of $7 \%$ over the thirty-year period 1990-2020 (Economic Planning Unit, 2016). This development is associated with economic growth. In the green "common future", as advocated in the Brundtland Report (1987), "sustainable development" has become the motto of the day: that is, to sustain development itself, rather than to sustain nature and culture (Blewitt, 2015; Esteva \& Prakash, 1998). In addition, sustainable development in developing countries has been increasingly interpreted in line with a strictly Western-centric value system (Abdulrazak \& Ahmad, 2014; Banerjee, 2003), and has marginalised local cultural knowledge about what constitutes sustainable development (Blewitt, 2015).

In relation to developing countries, like Malaysia, many observers have noted that the ideas of "progress", "modernity" and "development" hold Western economic structure and society as a universal model for others to follow and emulate (Escobar, 1995). Globalisation integrates not just the economy but culture, technology and governance. For example, some researchers (e.g., Evans, 2011; Kopnina \& Meijers, 2014) critique the overarching ESD objective as forced on developing countries by neo-colonial regimes. Evan (2011) argued that the spread of Western-style formal education undermines indigenous culture and knowledge, and enforces a sense of inferiority in local people as they struggle to achieve the Western goal of sustainability. Jickling (2005) warns that ESD risks becoming instrumental in indoctrinating students about the predetermined idea of sustainability by organisations such as the World Bank and UNESCO. Furthermore, mainstream discourse on sustainable development tends to ignore the deep ecology perspective and exhibit anthropocentric bias (Kopnina, 2012) arguably absent from traditional societies' learning practices (Anderson, 2012).

ESD practices in Western universities are questioned regarding their universal 
applicability to other countries (Kopnina \& Meijers, 2014). This is because different sustainability issues are crucial in different countries. For example, the report, A Million Voices: The World We Want (UNDG, 2013), captures the results of an unprecedented global conversation on the vision for the post-2015 development framework, involving more than one million people from all around the world. Malaysia's top three priorities in the report are "Good education", "An honest and responsive government" and "Protection against crime and violence" followed closely by "Better healthcare" and "Protecting forests, rivers and oceans." The main differences between Malaysian participants and the global results are that respondents from Malaysia highly rank "An honest and responsive Government", "Protection against crime and violence" and, similarly to the rest of Asia, "Protecting forests, rivers and oceans." Contrary to the global results, but more in accordance again with Asia, Malaysia gave less weight in terms of priorities to "Better healthcare" and "Better job opportunities" $\left(4^{\text {th }}\right.$ and $6^{\text {th }}$ places, respectively). Therefore, to enact ESD in Malaysian HEIs, the context of local sustainability issues is one of the important factors to be considered. This study will investigate how local sustainability issues are being considered by the participants as the important stimuli for ESD enactment in University A.

\section{Methodology}

The case study design was chosen as the research design because the behaviour of those involved in the study cannot be manipulated; and contextual conditions are required because they are relevant to the phenomenon under study. The researcher didn't have the extent of control over the participant's behaviour. An understanding of the contextual conditions in this study, Malaysian culture, religious influence, and Malaysia's political and economic agenda was required in understanding ESD at University A. The case of ESD in University A, could not be considered without an understanding of the context within which it occurred because sustainability is the ability of a system to sustain itself in relation to its environment (Sterling, 2004). This study is explanatory and may give insight to understand ESD enactment in HEI especially in Asian and developing country context.

In this paper, the dataset comprises the interviews with six lecturers, and the analysis of University A policy documents concerning sustainability. The interviews were conducted with six lecturers (i.e. L1, L2, L3, L4, L5, and L6) involved in ESD teaching and research. Relevant features of lecturer backgrounds and related working experience will accompany data excerpts to contextualise their responses. The use of University A policy documents concerning sustainability provides rich data sources of how HEIs incorporate sustainability in the institution, and ESD in the curriculum. In this study the interpretivist approach is used to interpret and understand the interconnection of the elements in this study.

Several themes emerged as the interview progressed from discussion of systems structure of ESD in University A. The key question concerning system structures of ESD in University A was, "What are the drivers and barriers to implement ESD in University A?". This question was initial prompts that gave rise 
to related issues or themes which set the conversation during the interview to move forward and to branch out to the various themes of systems structure of ESD in University A.

In this paper, the findings were presented in two sections to provide the context of the data. The first section relates to University A policy in sustainability. The second considers what the lecturers' comments concerning: a) The drivers of ESD in University A; b) Global influence in ESD; and c) The barriers of ESD in University A.

\section{University a Policy on Sustainability}

In this section, the analysis of University A policy concerning sustainability initiatives will be present. This section also will present the intersection between University A's timeline in its sustainability initiative with timeline of global sustainability initiatives, Malaysia's effort towards sustainability, and political transformation in Malaysia (illustrated in Figure 1). The intersections provide the context and temporal perspective on University A policy and sustainability initiatives.

\subsection{University a Policy on Sustainability and Its Intersection with Local and Global Policy}

To understand how University A sustainability policy is being framed, we need

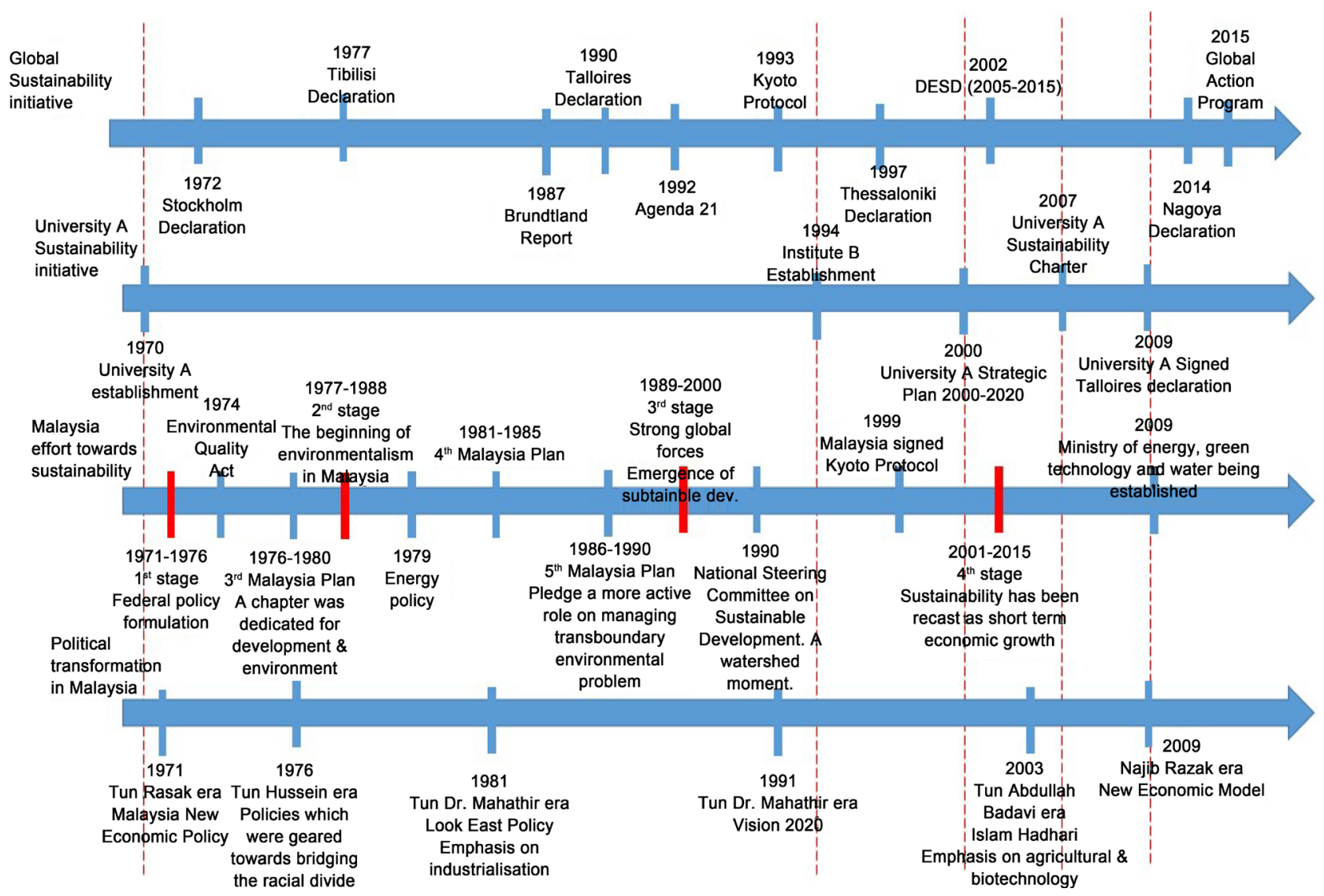

Figure 1. Intersection of University A sustainability initiatives with local and global sustainability initiatives, and with political transformation in Malaysia. 
to look at the context of University A that encompassed the political transformation during the policy being established, and the local and global factors that drive the policy enactment.

The dotted line in Figure 1 illustrates the intersection of University A sustainability initiatives with global and local sustainability agendas, and also the intersection with political transformation in Malaysia. The time period under analysis in this study is 1970 until 2015. In this section, the focus is the intersection between these timelines, to understand the context of the establishment of University A sustainability policy.

Over the last fifty years, Malaysia has undergone rapid economic and social change, and this process is ongoing. Malaysia's heavy reliance on natural resources was a salient feature of the economy from colonial days up until 1970 (World Bank, 2015). The year, 1970, was also when University A was established. During the first stage of efforts toward sustainability (1971-1976), Malaysia tried to introduce measures to monitor the balance between social and economic goals and the protection of environmental conditions. However, University A's involvement in sustainability was quite delayed, until the establishment of Institute B in 1994. This delay might be attributed to the different focus of University A during its early establishment, which did not focus on sustainability. Institute B was established to fulfil University A's aspirations, as envisioned by The United Nations Conference on Environment and Development (UNCED) held in Rio de Janeiro in 1992 (establishment of Agenda 21 during UNCED), to realise the goal of sustainable development through research and capacity development. The period 1989-2000 was the third stage of Malaysia's efforts towards sustainability. During this third stage, the influence of global forces on Malaysia's sustainability initiatives was strong, and the concept of sustainable development was emerging in Malaysia (Hezri, 2011). Institute B was established to serve as a reference centre capable of dealing with environment and development issues, assisting government in formulating policies based on research of a holistic and balanced kind. The rapid loss of the Malaysian rainforests in the $20^{\text {th }}$ century is closely linked to economic development. Not only were large areas of agricultural land developed for rubber and oil palm, logging activities also intensified in response to increasing demand for timber from overseas markets (Hezri \& Nordin Hasan, 2006). By the mid-1990s, Malaysia's economy was dominated by industrialisation because Malaysia's Vision 2020 aimed to transform Malaysia into a developed country by 2020, requiring 7\% economic growth per year. While economic achievement has advanced human development and reduced poverty, the pursuit of socioeconomic progress has been accompanied by an unprecedented rate of change in the natural environment. The accelerated change in the natural environment has stimulated the lo$\mathrm{cal}$ and global government to respond to this problem. The responses can be observed in environmental policy, sustainability declarations, and strategic plans at the national and international levels.

The formulation of environmental policies by the government has had a per- 
vasive influence in the formulation of University A's environmental policy and the utilisation of science and technology in University A (Choy \& Lau, 2013). The government's shift from a narrow environmental to a broader sustainable focus since the third and fourth stages (see Figure 1), has influenced the university to adopt a sustainable approach. In 2009, the Malaysian government made a serious effort towards achieving a sustainability approach through the establishment of the Ministry of Energy, Green Technology and Water by former Malaysian prime minister Tun Abdullah Badawi. In line with the country's development towards sustainability, in 2009 University A signed the Talloires Declaration. However, from the perspective of a policy analysis, Malaysia was a pioneer in the 1970s in establishing a framework for environmental governance. However, its response to the post-1992 (Agenda 21) sustainable development agenda has been patchy and haphazard (Hezri \& Nordin Hasan, 2006). Brosius (1999) argues that the lack of the Malaysian Government's political commitment to sustainable development during post-1992 originates in the ideological stance of the former Prime Minister, Tun Dr. Mahathir, who believed the concept of sustainable development was espoused by some developed countries for "ecoimperialistic" ends. This view was pervasive in government reform post-1992 (Hezri, 2011) and also in Malaysia's Look East Policy. This demonstrated that the role of normative change in political transformation impacted the sustainability initiatives in Malaysia and in University A.

The aspiration towards a sustainable campus has led to several initiatives being implemented by University A. These include the preparation of University A's Campus Physical Development Master Plan in 2006, the launch of University A's Sustainable Charter in 2007, and University A's Sustainable Research Cluster in 2007. University A's Sustainable Charter (2007), consists of six main principles:

1) Display practices that enhance the sustainability of institutions and universities by giving preference to suppliers who practice sustainable development;

2) Enhance community well-being and productivity;

3) Improve the health of campus ecosystems;

4) Promote environmental research and the development of institutions in terms of sustainability;

5) Develop planning tools to support decision-making that is responsible; and

6) Use sustainability indicators to monitor, report and continuously improve sustainability.

The establishment of University A's Sustainable Charter aims to coordinate research and implementation of sustainable development by the faculties, institutes and departments in the university. From the CAS perspective, the University A Sustainability Charter provides control to the agents in the organisation concerning their roles, the set of goals it is trying to achieve, and other agents with which it may coordinate. To implement the University A Sustainability Charter, the University A Sustainable Framework, consisting of University A's Sustainable Campus Research Cluster, was established in 2008. It outlines the 
role and coordination of agents.

Three main research groups were established in the University A Sustainable Campus Research Cluster:

1) Sustainable Community Research Group;

2) Ecosystem Management Research Group; and

3) Sustainable Design Research Group (later changed to Sustainable Physical Development Group).

From a CAS perspective, the University A Sustainable Research Cluster provides feedback to the organisation through the research conducted by each research cluster. The agents in each research cluster also communicate at the application-specific level, which includes the coordination between agents that allows them to carry out their assigned roles. These research cluster groups act as an effector of sustainability initiatives in University A.

The University A Sustainability Framework outlines three main aspects of a sustainable campus: community, ecosystem, and physical development. On the other hand, the Campus Sustainability Assessment Framework (CSAF) and the Sustainability Tracking Assessment and Rating System (STARS) place more emphasis on community and ecosystem components than on physical development. As such, physical development is not taken as a key component of the CSAF and the STARS sustainability assessment. However, in the University A Sustainability Program Framework, physical development is one of the key aspects, apart from the community and ecosystem. The University A Sustainability Framework demonstrates that while environmental management (i.e. Sustainable Ecosystem Management Group \& Sustainable Physical Development Group) is given more focus, a sustainable curriculum is marginalised. Sterling and Scott (2008) argue that environmental managers have to take the university's environment seriously, because there is a clear legal and regulatory framework within which they have to act, and clear financial incentives to do so. Academics, however, don't have to take sustainability seriously, except to the extent that there is accreditation pressure, or that they are interested or that, perhaps, students demand it, and academics usually resent being told what their job entails (Sterling \& Scott, 2008).

Internationalisation and global competitiveness have influenced University A and can be traced to Strategy 4 of the University A 2000-2020 strategic plan, which aims to lead University A to the international level and global recognition. In Malaysia's Education Blueprint 2015-2025 (MOE, 2015), the Malaysian Ministry of Higher Education recognises that the education system in Malaysia needs to keep evolving to stay abreast and ahead of global trends. The Ministry's overriding aspiration is to "create a higher education system that ranks among the world's leading education systems and that enables Malaysia to compete in the global economy" (MOE, 2015: p. 11).

The analysis of documents (i.e. University A Sustainability Charter, University A Strategic Plan 2000-2020, University A Sustainable Framework) demonstrate that University A has a specific policy and principles concerning sustainability 
enactment in University A. These policies intersect with local and global development on sustainability initiatives and political transformation in Malaysia. The University A Sustainability program framework outlines three main aspects of a sustainable campus, namely, community, ecosystem, and physical development. However, compared to a curriculum for ESD, more emphasis is being placed on the Sustainable Ecosystem Management group and Sustainable Physical Development Group.

\section{The drivers of ESD in University A}

This section presents the responses from the six lecturers concerning the drivers of ESD in the university A. The drivers of ESD in University A were understood by the participants in either of two ways: the driver was understood as the person that need to drive the ESD enactment in University A; or as the one that provides the stimulus, impulse or motivation for ESD enactment in University A.

The lecturers' responses fell into two categories:

- Organisational support as an effector/driver of ESD in University A

- Global influence on ESD in University A

\subsection{Organisational Support as an Effector/Driver of ESD in University A}

The theme of organisational support as the driver of ESD in HEIs supports the concluding report of the Decade of Education for Sustainbale Development (DESD) (Shaping the Future We Want ) (2014) that identified a need for more work towards institutionalizing ESD to ensure strong political support for implementing ESD on a systemic level. Organisational support as an effector/driver for ESD was argued by L1, L6, and L4. L1 gave an extensive explanation when asked the question concerning the drivers of ESD enactment in University A. Perhaps because of her vast experience as a lecturer at University A for more than 30 years, and perhaps also because she was in the top management at University $A$, she could provide a detailed explanation of tension in the systems structure in University A to enact ESD. She stated:

In higher education we have different 'cars'. The top management, they drive Mercedes, then the professors, the lecturers, and the students. We have many drivers. Each driver must understand what they want to do. Then it is not just from top to bottom approach. That is why we have reports. So that information from the bottom goes up. So it has to be two ways. It cannot be just one way ... The important thing is communication between these people; people at the top and people at the enforcement level ( $L 1$ 's's interview).

She also acknowledged the importance of two-way communication in the university's organisation. The sustainability policy established at the top level should be passed down for enforcement. Then feedback, reports from the implementation, and information on the sustainability problem should also reach the top management level. L1's suggestion supports Velazquez et al.'s (2005) 
argument that to promote effective sustainability, a functionally integrative organisational structure is recommended. This is because decisions can be more quickly addressed. However, the university's organisational structure is characterised by its lack of integration due to its decentralised management and bureaucracy. The driver of ESD in University A involves how the communication and information is articulated within the organisation. Furthermore, L5 also argued that the top management is a driver for ESD enactment in University A. She stated;

We need support from the leaders. Support from top management. If the top management think that sustainability is important then the research grant for sustainability will be flourishing (L5's interview).

As noted here, L5 argued that the composition of University A top management can influence sustainability research opportunities. Leadership within and across education systems will be essential to sustain efforts and ensure ESD objectives are adopted and put into action. This means leadership at the global, regional, national and local levels will be needed to create the organisational climate necessary for change, to put the resources in place to secure change and to provide encouragement for all actors to experiment, take risks, learn and adapt to move societies towards sustainability.

Organisational support can also be in the form of giving autonomy to lecturers to develop their own expertise. L6's background in environmental philosophy and her position in the top management in the university might contribute to her conceptualisation of the factor that drives her motivation for involvement in ESD teaching and research. She perceived the university policy that gives autonomy and opportunity to the lecturer to develop their own expertise as the driver for ESD in University A. She stated:

What drive me to teach sustainability is because I have the autonomy. I developed the course, I teach, and evaluate the course. So the autonomy is quite strong when you in tertiary education compared to school. The policy in this university gives the autonomy to the lecturer. Second, the driver is the policy and top management in the university, is not giving difficulties to any lecturers to develop their expertise. We have grant and many thing. Drivers are many, but we have to be diligent. To use grant, look for research grant. That is the thing that drives me to involve in sustainability teaching and research, because you have the avenue, and financial. You just have to ask for it, looked for it and use it. Environment in University $A$ is quite conducive. As far is this your field you can do it ( L6's interview).

Note here that L6's point focused on autonomy and academic freedom in the university. She compared autonomy at the university and the school level. She argued that the policy in University A does not restrict academics from developing their expertise in any fields. Furthermore, University A, as one of the research universities in Malaysia, has a fair amount of autonomy (Choy \& Lau, 2013). L6's claim that university policy encouraged her to develop her expertise in sustainability and be involved in ESD is consistent with Holmberg and Samu- 
elsson's (2006) position. They argue that academics' autonomy and freedom in universities has a profound role to play in ESD, in terms of developing student qualities to cope with uncertainty, poorly defined situations, diverging norms, values, interests and reality constructions.

\subsection{Global influence on ESD in University A}

L4 argued that global influence is the driver of ESD in University A. Her previous master degree in political science might contribute to her awareness about global influence in a developed country like Malaysia. She stated:

I think the pressure is because of global issues. We see that other universities have sustainability course in their university. And of course Malaysia has to go for that too. Especially the top university they have various sustainability courses, and of course we need to compete with this university ( $L 4$ 's interview).

L4's interview extract demonstrates that she conceptualised University A enactment of ESD as an accommodative response to the concerns of sustainability at the global level. At the global level, over one thousand university presidents and vice-chancellors have signed the sustainability-related declaration, committing their institutions to change towards sustainability. A detailed description and chronology of the sustainability declarations signed by the university presidents is provided in Chapter 2. International declarations may provide useful publicity to encourage progress of ESD (Ryan et al., 2010). From the Talloires Declaration (1990) to the more recent Global Action Program (2015), these initiatives have all encouraged HEI engagement in ESD. The University Leaders for a Sustainable Future (ULSF), which formed in 1990, initiated the signing of the Talloires Declaration by 22 universities (UNESCO, 1990). In 2009, University A joined the ULSF and, in keeping with that declaration, University A is required to act as a role model in the sphere of sustainable development in HEIs. According to L4, University A's endeavour to compete at the global level and to internationalise its program and contribution has driven the ESD initiative in University A, as sustainability is becoming increasingly pertinent to global higher education (Levy, 2012; Sterling, 2004; Tilbury, 2004). University A's initiative in sustainability had started before University A signed the Talloires Declaration in 2009. University A had commenced the move towards sustainability by establishing, on October 1, 1994, the Institute for Environment and Development (Institute B) aimed at carrying out multidisciplinary research and training activities in the field of sustainability. L4 is one of the academics in Institute B. Furthermore, in 2007, University A's Sustainable Campus Programme was established.

On the other hand, L1 argued about global influence in ESDhas positive and negative implications. L1, who received her higher education in the United Kingdom and has working experience in an overseas international organisation, alluded to these potential positive and negative effects. She stated: "Globalisation has influenced us. Like you-you are studying overseas, and are bringing back what is good or maybe is bad to implement in Malaysia" (L1's interview). Her 
claim is consistent with Kopnina and Meijers' (2014) argument about whether or not all the ESD practice examples in western universities are universally applicable. Countries where ESD is practiced differ greatly in their socio-political priorities, and in their political, ecological, and economic factors. ESD in developing countries differs from that in developed ones. This suggests that it is necessary to examine the assumptions or values that inform ESD enactment at the university. The approach should involve critical reflection on the assumptions and values of the paradigm, resulting in an attempted 'building-in' (i.e. embedding) of sustainability ideas in ESD enactment, and a reorientation of the existing system in HEIs (Jones, Selby, \& Sterling, 2010). Malaysia is a developing country comprised of a Muslim majority population, as well as other ethnic communities, so a Western-centric interpretation of sustainable development may pose several issues. One of these is that making developing countries more economically competitive and sustainable requires not only the injection of capital and the transfer of technology, but also a cultural transformation, because many "old ways" of living may create obstacles to sustainable development. The ideals, mental habits, patterns of work, and modes of knowing in which a developing country's people are steeped, are often at odds with the ethos of an economic society. In an attempt to overcome these barriers to growth, the traditional social fabric is often dissected and reassembled according to the Western-centric interpretation of sustainable development (Sachs, 1999).

\section{The Barriers of ESD in University A}

The themes that emerged describe the lecturers' perceptions of factors that deter ESD enactment in University A. The responses from the lecturers fall into five categories:

- Lack of sustainability awareness

- Sustainability acceptance is influenced by discipline

- Limited financial support

- Passive adaptive organisational culture

- Compartmentalised education system

\subsection{Lack of Sustainability Awareness}

During the interview, L4 stated she perceived the lack of awareness among the important stakeholders in curriculum development as the barrier to implementing ESD. She stated:

The barrier is that the people that are responsible in developing curriculum. They are not aware of the importance of sustainability. They have the other issues they want to tackle first, because they think sustainability is not important. For example our education system always goes for quantity. They want many students to get A's. But what about quality? If we don't change that kind of mindset then it is very difficult to proceed with sustainable education, because we are not teaching the student to make them knowledgeable about sustainability but we want them to score $A$ in the exam (L4's interview). 
L4 claimed the people who developed the curriculum in the Malaysian education system have priorities in education other than a sustainability agenda. She raised her concern about a Malaysian education system that prefers quantifiable outputs. The codes assigned during the data analysis to L4's feedback about barriers to implementing ESD in HEIs are: "lack of awareness among important stakeholders in education system", and "sustainability is not the priority in the education system". L4's concern over the difficulty in incorporating sustainability in HEI curricula is supported by Dawe et al.'s (2005) study, which recognises limited staff awareness that discourages cultural change towards sustainability as one of the major barriers to the successful embedding of ESD into many of the subject disciplines in HEI.

Furthermore, L2 raised the issue of a lack of sustainability awareness among senior management in HEIs:

I think the top management also need to have awareness about sustainability issues, because sometimes they are more focused on administrative works and they can't see the connection to sustainability problems (L2's interview).

L2's suggestion of the necessity for the top management to have sustainability awareness is based on a premise; sustainability awareness is a key element in furthering more sustainable practices in HEIs. Before addressing practices, there must be a basic belief that there are or could be sustainability problems (Shadymanova et al., 2014). L2's claims about a lack of sustainability awareness among university management are consistent with a study by Velazquez et al. (2005), which demonstrated that people in charge of sustainability in HEIs often complain about university's management that is unaware of or has no interest in sustainability. This will delay the systemic transformation in HEIs towards sustainability, and delay the incorporation of sustainability in HEI curricula (Dawe et al., 2005).

\subsection{Sustainability Acceptance is Influenced by Discipline}

Furthermore, L4, who is an academic at Institute B, argued that non-practitioners find it difficult to accept sustainability. She stated: "When I talk with friends outside the environmental group, it is quite difficult. They say it is not relevant to their discipline" (L4's interview). While practitioners in the sustainability field might understand the term 'sustainability' and the relevance of sustainability across the disciplines, the term itself is not easily understood by non-practitioners. Therefore, there is a big gap in understanding between non-practitioners and sustainability practitioners (Birdsall, 2014; Garbie, 2015). According to L4, it is difficult to convince the academic staff members who are not in sustainabilityrelated disciplines to accept sustainability, because they perceive sustainability as irrelevant to their discipline. L4's claim corroborates works by Dawe et al. (2005), Filho (2000), Holdsworth (2010), and Sterling (2012), that recognise one of the barriers to the successful implementation of ESD in HEIs to be the perception of some academic staff that sustainability is irrelevant and an awkward fit with certain subject areas. Cotton et al. (2009) recognises an overall patchy 
picture, with sustainability being marginal or non-existent in some key disciplines but of increasingly high profile in others, and this is contributed to by different perceptions of sustainability, and how, or indeed if, it should be pursued in HEIs.

L3's disciplinary background is building and facility management. She stated that in her discipline, there is no barrier to implementing ESD in University A because she assumed the disciplinary background of the faculty members play a part. She said:

In my faculty I do not see any barrier to implement ESD, maybe because the members of the faculty come from the same background, and we aware about importance of sustainability. But in the context of public, the context of general education in Malaysia, I can see maybe some barriers, due to lack of awareness among Malaysian ( $L 3$ 's interview).

However, in the general Malaysian education context, she perceived lack of sustainability awareness as becoming the barrier to implementing ESD in HEIs. L3's quote above also demonstrated that she perceived in a different context, such as in different faculty, that there are different levels of sustainability awareness. That disciplinary background played a role in sustainability awareness was also reflected in L2's response concerning barriers to implementing ESD in University $A$. There is a common belief among academics and the public that the life sciences, and disciplines such as geography and biology, accommodate ESD more readily than other disciplines (Cotton et al., 2007). One of the causes for the lag in ESD curricula is because of the perception that ESD is irrelevant in particular disciplines (Dawe et al., 2005), although some argue that ESD can be linked to any field (Sterling \& Thomas, 2006).

L2 perceived disciplinary background as playing a role in sustainability awareness. She stated in her faculty (Life sciences related disciplines), there is no barrier to implementing ESD because Biology students understand the concept of sustainability. Furthermore, as practitioners who work in a sustainability related discipline, she assumed most academics in her faculty have sustainability awareness. However, she expressed uncertainty about how people in other disciplines understand sustainability. She stated:

In my area, I think not really have barrier, because it is Biology. Most of the students love nature. They understand the concept of conserving the biodiversity and sustainability for the next generation. As practitioners I think most of us have awareness for sustainability. But for another discipline $1 \mathrm{~m}$ not sure how they understand and perceived sustainability in their area. (L2's interview).

This quote was coded as 'discipline background plays a role in sustainability awareness'. In this study, the participants worked in disciplines that required them to focus on sustainability, and they regarded themselves as practitioners. L2 compared her own awareness with her colleagues' awareness of sustainability. She stated, "As a practitioner, I think most of us have an awareness of sustainability. But for another discipline, I $m$ not sure how they understand and perceive sustainability in their area" (L2's interview). When she mentioned "most of us" 
she was referring to herself and her colleagues in the Biology program. Her concerns about the understanding of sustainability in other disciplines demonstrated that her assumptions about sustainability might be perceived differently or as irrelevant in other disciplines. L2's assumption about other disciplines is consistent with Dawe et al.'s (2005) view, which recognises that in certain disciplines such as Engineering, Geography, Earth Studies and Bioscience, the urge to enact sustainability in the curriculum is high. However, in other disciplines such as Computer Sciences, Mathematics, Statistics, Operational Research, Performing Arts, and Psychology, the subject centres have an interest in ESD, but have found it much more difficult to embed ESD widely or deeply into their curricula. There is a common belief among academics and the public that the life sciences, and disciplines such as geography and biology, accommodate ESD more readily than other disciplines (Cotton et al., 2007).

On the other hand, L6, who is from an environmental philosophy background, claimed that she didn't see any barrier to implementing ESD in University A. This is because the sustainability concept is easily accepted by the people in the university, even those from different fields of study. She shared her experience when she collaborated with academics in Islamic study to do sustainability research.

I don't see any barriers. As far my experience is concern, whenever I bring sustainability issues in area of studies, I have no problem. Is not that I have a feedback that we don't need this. Recently I am working with Islamic studies. None of the professor in Islamic studies is saying we don't need this, they are very welcoming and sporadically forming group Islam and environment. I didn't find it contradicting or unacceptable when talking about issues of sustainability. My task is to influence more people in many disciplines and use their expertise in handling tackling sustainability issues (L6's interview).

L6 argued that lecturers in all disciplines, including the lecturers who are not working in sustainability-related fields, can accept the idea of sustainability very well. The researcher assuming L6's position in the top management in University A may contribute to influencing academics to accept sustainability agenda introduced by her. Otherwise, the academics approached by L6 may already understand sustainability to some degree. This is because sustainability acceptance comes from sustainability understanding (Christie, Miller, Cooke, \& White, 2012); thus, this suggests that academic staff who accept sustainability do so from a basis of sustainability understanding. L6's elaboration demonstrated that acceptance begins with conscious awareness. In the first place, academic staff in the Islamic Studies Faculty are aware of sustainability, thus they can accept the sustainability concept. To accept sustainability, they need to acknowledge that there are or could be sustainability problems (Shadymanova et al., 2014). Furthermore, the interview excerpt above demonstrates that acceptance requires actual work, such as the academic staff in the Islamic Studies Faculty who "sporadically formed the group, Islam and environment". This provides evidence of their acceptance of sustainability. 
L6's response concerning barriers to implementing ESD in HEIs is slightly different from the rest of the participants. While L3, L4, and L2 believe that disciplinary background influences people's sustainability awareness, L6 claimed that the concept of sustainability is easily accepted by the people in the university, even from those in different fields of study. Furthermore, L6's claim that the concept of sustainability is easily accepted by the people in university, contrasts with L4's response that important stakeholders in the education system are not aware of the importance of sustainability, therefore they prioritise goals other than sustainability in the education system. These contradictory responses by L6 raised related issues or themes which demonstrated the 'dissonance of perspectives' concerning the barriers to ESD implementation in University A.

\subsection{Limited Financial Support}

Meanwhile, L5 believed there is no barrier to implementing ESD in HEIs when asked the question: 'What is the barrier of ESD in University A?". She stated, " $I$ think there is no barrier. My concern is whether sustainability knowledge and awareness that we promote is reaching the target people or not' (L5's interview). However, later in the interview when she was asked the question concerning the drivers for ESD in University A, she also discussed the barriers to ESD implementation in University A. She stated: "This university is flexible, but now we do not have much money. The opportunity is wide, but the probability to get the grant is uncertain" (L5's interview).

\subsection{Compartmentalised Education System}

In addition, L5 raised her concerns about compartmentalisation in the education system becoming a barrier and discouraging interdisciplinary skill among educators. She stated, "Our education system is much compartmentalised. So, not everyone has the interdisciplinary skill. That is the barrier if we want to integrate sustainability in our curriculum" (L5's interview). L5's concern about a compartmentalised education system deterring the progress of ESD, which requires an interdisciplinary approach, is consistent with Mc Keown's (2002) and Erdogan and Tuncer's (2009) studies. These studies recognise that one of the obstacles to incorporating ESD in HEIs is the difficulty of fitting the interdisciplinary content of ESD into a discipline-oriented educational process. The theme emerging from this quote is 'compartmentalised education system'. L5's working experience in the Centre for General Studies (focusing on interdisciplinary learning) and her disciplinary background in environmental management (with an interdisciplinary focus) might contribute to her concern about the problem of compartmentalised education systems and ESD learning and teaching.

In conclusion, barriers to ESD enactment in University A are encompassed in individual agents in the organisation, systems in the organisation, and organisational culture. The barriers that involved individual agents can be observed in lack of sustainability awareness, with sustainability acceptance being influenced by the nature of their disciplinary backgrounds. Meanwhile, barriers in the sys- 
tem concerning the compartmentalised education system contribute to the difficulty in incorporating interdisciplinary ESD. Furthermore, the barriers to ESD enactment also involve the culture of the organisation. The participants argued that the passive adaptive organisational culture will slow down the effort to implement ESD in University A.

\section{Conclusion}

In conclusion, the findings paper demonstrated that the participants/lecturers/ agents' interaction within their cluster/group is collaborative and cooperative, and the interaction across the clusters is conflicting. However, if the interaction across the clusters is between different levels (top management to academics), the interaction is cooperative. The interaction between agents in the organisation is influenced by their academic backgrounds, working experience, positions and interests. These findings that have presented in this paper suggest that, in University A context, to widespread ESD acceptance and implementation, it needs to be more on top-down enforcement. This is because the interaction between clusters between different levels (top management to academic) is cooperative.

In terms of environmental stimuli for ESD in University A, the findings from this study demonstrate that the agents' individual systems and the organisational system are co-evolving with their environment. The changes in the environment, such as the accelerating sustainability crisis and global influence, are perceived by the lecturers as stimulating ESD enactment in the university. University A's response to the sustainability agenda involves temporality and selection. This is because every system has a signal/stimulus list. If the detected stimulus is in the system list, the effector in the system will create a response to adapt with the environment. This finding on environmental stimuli for ESD in University A, suggests that local and global factors influence the enactment of ESD in the university. Therefore, to understand the enactment of ESD in the university, the local and global context of the institution needs to be considerate, especially in developing country such as Malaysia, there is an obsession to remain competitive and follow global trends. However, one limitation is that the interviews with the lecturers were conducted at a snapshot in time, whereas change and co-evolution between agents, systems and their environment is a longitudinal process.

Despite the forces to adapt to environmental changes, within a system there is resistance to change. In this study, it includes: the lecturers' perceived lack of sustainability awareness; sustainability acceptance influenced by disciplines; limited financial support from the university; a compartmentalised education system; bureaucratic tensions; and lacking of teaching skills among ESD educators.

\section{References}

Abdulrazak, S. R., \& Ahmad, F. S. (2014). Sustainable Development: A Malaysian Perspective. Procedia-Social and Behavioral Sciences, 164, 237-241. 
Anderson, E. N. (2012). Tales Best Told Out of School: Traditional Life-Skills Education Meets Modern Science Education. In H. Kopnina (Ed.), Anthropology of Environmental Education. New York: Nova Science Publishers.

Banerjee, S. B. (2003). Who Sustains Whose Development? Sustainable Development and the Reinvention of Nature. Organization Studies, 24, 143-180. https://doi.org/10.1177/0170840603024001341

Bhandari, R., \& Lefeburee, A. (2015). Higher Education in Asia and the Search for a New Modernity: An Introduction. In Asia: The Next Higher Education Superpower? (pp. 7-13). New York, NY: The Institute of International Education.

Birdsall, S. (2014). Measuring Student Teachers' Understandings and Self-Awareness of Sustainability. Environmental Education Research, 20, 814-835. https://doi.org/10.1080/13504622.2013.833594

Blewitt, J. (2015). Understanding Sustainable Development. New York, NY: Earthscan.

Boni, A., Lopez-Fogues, A., \& Walker, M. (2016). Higher Education and the Post- 2015 Agenda : A Contribution from the Human Development Approach. Journal of Global Ethnics, 9626, 16-28. https://doi.org/10.1080/17449626.2016.1148757

Brodie, C. A. (2006). Environmental Sustainability Programs in Higher Education: Policies and Curriculum Strategies. University of the Pacific Stockton.

Brundtland Report (1987) Report of the World Commission on Environment and Development: Our Common Future. http://www.un-documents.net/wced-ocf.htm

Cheng, Y. C. (2005). New Paradigm for Re-Engineering Education: Globalization, Localization and Individualization. Berlin: Springer.

Choy, E. A., \& Lau, C. (2013). Towards a Sustainable Campus: An Ecological Modernization Perspective. Asian Social Science, 9, 106-110. https://doi.org/10.5539/ass.v9n14p106

Christopher, F., \& William, T. (2010). Globalisation and Tertiary Education in the Asia-Pacific: The Changing Nature of a Dynamic Market. Singapore: World Scientific Publishing Co.

Cotton, D. R. E., Warren, M. F., Maiboroda, O., \& Bailey, I. (2007). Sustainable Development, Higher Education and Pedagogy: A Study of Lecturers' Beliefs and Attitudes. Environmental Education Research, 13, 579-597.

https://doi.org/10.1080/13504620701659061

Cotton, D., Bailey, I., Warren, M., \& Bissell, S. (2009). Revolutions and Second Best Solutions: Education for Sustainable Development in Higher Education. Studies in Higher Education, 34, 719-733. https://doi.org/10.1080/03075070802641552

Dawe, G., Jucker, R., \& Martin, S. (2005). Sustainable Development in Higher Education: Current Practice and Future Developments. New York.

Derahim, N., Hashim, H. S., \& Ali, N. (2011). The Level of Sustainability among Students of Universiti Kebangsaan Malaysia towards Sustainable Campus. Jurnal Personalia Pelajar, 273, 1-10.

Erdogan, M., \& Tuncer, G. (2009). Evaluation of a Course: "Education and Awareness for Sustainability." International Journal of Environmental and Science Education, 4, 133146.

Escobar, A. (1995). Encountering Development: The Making and Unmaking of the Third World. Princeton, NJ: Princeton University Press.

Esteva, G., \& Prakash, M. S. (1998). Beyond Development, What? Development in Practice, 8, 280-296. https://doi.org/10.1080/09614529853585

Esteva, G., Babones, S., \& Babcicky, P. (2013). Future of Development: A Radical Manifesto. Bristol: Policy Press. 
Evans, T. L. (2011). Living and Learning Sustainability: Pedagogy and Praxis in Sustainability Education. PhD Thesis, Prescott College.

Evans, T. L. (2011). Living and Learning Sustainability: Pedagogy and Praxis in Sustainability Education. Prescott, AZ: Prescott College.

Fadzil, Z. F., Hashim, H. S., \& Aziz, S. (2012). Developing a Campus Sustainability Assessment Framework for the National University of Malaysia. World Academy of Science, Engineering and Technology, 751-755.

Filho, W. L. (2000). Dealing with Misconceptions on the Concept of Sustainability. International Journal of Sustainability in Higher Education, 1, 9-19. https://doi.org/10.1108/1467630010307066

Garbie, I. H. (2015). Sustainability Awareness in Industrial Organizations. Procedia CIRP, 26, 64-69.

Global Action Program (2015). http://unesdoc.unesco.org/images/0024/002462/246270e.pdf

Hadi, A. S., Jelas, Z. M., Mokhtar, M. B., \& Farina, Y. (2002). Universiti Kebangsaan Malaysia, the National University with an International Reach: Opportunities and Challenges in the 21st Century. In Australian International Education Conference (pp. 1-10). Hobart.

Hezri, A. (2011). Sustainable Shift: Institutional Challenges for the Environment in Malaysia. Akademika, 81, 59-69.

Hezri, A., \& Nordin Hasan, M. (2006). Towards Sustainable Development? The Evolution of Environmental Policy in Malaysia. Natural Resources Forum, 30, 37- 50. https://doi.org/10.1111/j.1477-8947.2006.00156.x

Holdsworth, S. (2010). A Critique of Academic Development in Sustainability for Tertiary Educators. RMIT University.

Holmberg, J., \& Samuelsson, B. E. (2006). Drivers and Barriers for Implementing Sustainable Development in Higher Education. Paris. http://www.unesco.org/education/desd

Jickling, B. (2005). Sustainable Development in a Globalizing World: A Few Cautions. Policy Futures in Education, 3, 251-260. https://doi.org/10.2304/pfie.2005.3.3.3

Jickling, B., \& Wals, A. (2012). Debating Education for Sustainable Development 20 Years after Rio: A Conversation between Bob Jickling and Arjen Wals. Journal of Education for Sustainable Development, 6, 49-57. https://doi.org/10.1177/097340821100600111

Jones, P., Selby, D., \& Sterling, S. (2010). Sustainability Education: Perspectives and Practice across Higher Education. London: Earthscan. https://doi.org/10.1177/0739456X11404173

Joseph, C. (2013). Environmental Literacy and Attitudes among Malaysian Business Educators. International Journal of Sustainability in Higher Education, 14, 196-208. https://doi.org/10.1108/14676371311312897

Keser, H. Y. (2015). Effect of Higher Education on Global Competitiveness: Reviews in Relation with European Countries and the Middle East Countries. Economy Series, 1, 58-68.

Kopnina, H. (2012). Education for Sustainable Development (ESD): The Turn Away from "Environment" in Environmental Education? Environmental Education Research, 18, 699-717. https://doi.org/10.1080/13504622.2012.658028

Kopnina, H., \& Meijers, F. (2014). Education for Sustainable Development (ESD): Exploring Theoretical and Practical Challenges. International Journal of Sustainability in Higher Education, 15, 188-207. https://doi.org/10.1108/IJSHE-07-2012-0059 
Lattuca, L. R., \& Stark, J. S. (2009). Shaping the College Curriculum: Academic Plans in Context (2nd ed.). San Francisco, CA: Jossey-Bass Inc.

Levy, B. L. M. (2012). Towards a Campus Culture of Environmental Sustainability: Recommendations for a Large University. International Journal of Sustainability in Higher Education, 13, 365-377. https://doi.org/10.1108/14676371211262317

Mc Keown, R. (2001). Education for Sustainable Development Toolkit. Tennessee: Waste Management Research and Education Institution

MOE (2015). Malaysia Education Blueprint 2015-2025 (Higher Education). http://medcontent.metapress.com/index/A65RM03P4874243N.pdf

Mok, K. H. (2015). Higher Education Transformations for Global Competitiveness: Policy Responses, Social Consequences and Impact on the Academic Profession in Asia. Higher Education Policy, 28, 1-15. https://doi.org/10.1057/hep.2014.27

Nair, S. M. (2013). Malaysian Teacher Trainees Practices on Science and the Relevance of Science Education for Sustainability. International Journal of Sustainability in Higher Education, 14, 71-89. https://doi.org/10.1108/14676371311288967

Omar, Z., Saruwono, M., Mohammad, N., Darus, Z. M., Rashid, A. K. A., \& Hashim, N. A. (2009). Development of Sustainable Campus: Universiti Kebangsaan Malaysia Planning and Strategy. WSEAS Transactions on Environment and Development, 5, 273-282.

Ryan, A., Tilbury, D., Corcoran, P. B., Abe, O., \& Nomura, K. (2010). Sustainability in Higher Education in the Asia-Pacific: Developments, Challenges, and Prospects. International Journal of Sustainability in Higher Education, 11, 106-119. https://doi.org/10.1108/14676371011031838

Saadatian, O., Salleh, E., Tahir, O. M., \& Doha, K. (2011). Significance of Community in Sustainability of Malaysian Higher Educational Institutions. Pertanika Journal of Social Science and Humanities, 19, 243-262.

Sachs, W. (1999). Planet Dialectics. New York, NY: Fernwood Publishing.

Senge, P. M. (1990). The Fifth Discipline: The Art and Practice of the Learning Organization. Measuring Business Excellence (Vol. 1). New York, NY: Doubleday. https://doi.org/10.1108/eb025496

Shadymanova, J., Wahlen, S., \& Van Der Horst, H. (2014). “Nobody Cares about the Environment”: Kyrgyz' Perspectives on Enhancing Environmental Sustainable Consumption Practices When Facing Limited Sustainability Awareness. International Journal of Consumer Studies, 38, 678-683. https://doi.org/10.1111/ijcs.12140

Simon, D. (2006). Separated by Common Ground? Bringing (Post) Development and (Post) Colonialism Together. The Geographical Journal, 172, 10-21. https://doi.org/10.1111/j.1475-4959.2006.00179.x

SQW Limited (2006). Specialist Review and Evaluation of the Higher Education Partnership for Sustainability (HEPS) Programme. Cambridge.

Sterling, S. (2004). Higher Education, Sustainability and the Role of Systemic Learning. In P. B. Corcoran, \& A. E. J. Wals (Eds.), Higher Education and the Challenge of Sustainability: Problematics, Promise and Practice (pp. 49-70). Dordrecht: Kluwer Academic.

Sterling, S. (2012). The Future Fit Framework: An Introductory Guide to Teaching and Learning for Sustainability in Higher Education (pp. 1-76). York.

Sterling, S., \& Scott, W. (2008). Higher Education and ESD in England: A Critical Commentary on Recent Initiatives. Environmental Education Research, 14, 386- 398. https://doi.org/10.1080/13504620802344001

Sterling, S., \& Thomas, I. (2006). Education for Sustainability: The Role of Capabilities in guiding university curricula. . International Journal of Innovation and Sustainable Development, 1, 349-370. https://doi.org/10.1504/IJISD.2006.013735 
Talloires Declaration (1990). http://ulsf.org/wp-content/uploads/2015/06/TD.pdf

Tilbury, D. (2004). Environmental Education for Sustainability: A Force for Change in Higher Education. In P. B. Corcoran, \& A. E. J. Wals (Eds.), Higher Education and the Challenge of Sustainability: Problematics, Promise and Practice (pp. 97-112). Netherland: Kluwer Academic. https://doi.org/10.1007/0-306-48515-x_9

Tilbury, D. (2007). Monitoring and Evaluation during the UN Decade of Education for Sustainable Development. Journal of Education for Sustainable Development, 1, 239-254. https://doi.org/10.1177/097340820700100214

UNDG (2013). A Million Voices: The World We Want, a Sustainable Future with Dignity for All (p. 172). http://www.worldwewant2015.org/file/388792/view/422422

UNESCO (1990). The Talloires Declaration. http://www.ulsf.org/programs_tallories.html

UNESCO (2006). Globalization and Education for Sustainable Development. Paris: UNESCO.

Velazquez, L., Munguia, N., \& Sanchez, M. (2005). Deterring Sustainability in Higher Education Institutions. International Journal of Sustainability in Higher Education, 6, 383-391. https://doi.org/10.1108/14676370510623865

World Bank (2015). Classification Countries by Income. http://data.worldbank.org/

Zotzmann, K. (2007). Educating for the Future: A Critical Discourse Analysis of the Academic Field Intercultural Budinedd Communication. University of Lancaster.

Submit or recommend next manuscript to SCIRP and we will provide best service for you:

Accepting pre-submission inquiries through Email, Facebook, LinkedIn, Twitter, etc. A wide selection of journals (inclusive of 9 subjects, more than 200 journals)

Providing 24-hour high-quality service

User-friendly online submission system

Fair and swift peer-review system

Efficient typesetting and proofreading procedure

Display of the result of downloads and visits, as well as the number of cited articles

Maximum dissemination of your research work

Submit your manuscript at: http://papersubmission.scirp.org/

Or contact ce@scirp.org 